\title{
Building a Natural Hazard Insurance System (NHIS): The Long-Lasting Italian Case
}

\author{
Fabrizio Terenzio Gizzi ${ }^{1, *(\mathbb{D})}$, Donatella Porrini ${ }^{2}$ (D) and Francesco De Masi $^{2}$ (D) \\ 1 Institute of Heritage Science, National Research Council (ISPC-CNR), Area della Ricerca, C.da S. Loja, Tito, \\ 85050 Potenza, Italy \\ 2 Department of Management, Economics, Mathematics and Statistics, University of Salento, 73100 Lecce, Italy; \\ donatella.porrini@unisalento.it (D.P.); francesco.demasi@unisalento.it (F.D.M.) \\ * Correspondence: fabrizioterenzio.gizzi@cnr.it
}

check for updates

Citation: Gizzi, F.T.; Porrini, D.; De Masi, F. Building a Natural Hazard Insurance System (NHIS): The Long-Lasting Italian Case. Sustainability 2021, 13, 12269. https://doi.org/10.3390/su132112269

Academic Editor: George

D. Bathrellos

Received: 30 September 2021

Accepted: 31 October 2021

Published: 6 November 2021

Publisher's Note: MDPI stays neutral with regard to jurisdictional claims in published maps and institutional affiliations.

Copyright: (c) 2021 by the authors. Licensee MDPI, Basel, Switzerland. This article is an open access article distributed under the terms and conditions of the Creative Commons Attribution (CC BY) license (https:/ / creativecommons.org/licenses/by/ $4.0 /)$.

\begin{abstract}
The worrying growth of extreme natural events and their socioeconomic impact over time is increasingly fuelling the debate on how to manage disasters in view of developing resilient and sustainable societies. One possible financial tool may be represented by insurance against natural hazards, such as earthquakes, floods, and landslides. From this perspective, the current article considers legislative attempts to build a Natural Hazard Insurance System (NHIS) in Italy. The (never promulgated) bills proposed over a time span of about 30 years were analysed by: (a) A text-mining technique, considering the extraction of relevant data for the research; (b) the careful reading of the texts and their cross-correlated critical analysis. Approximately forty bills have been proposed since the 1980s and they mainly concern the proposal of an NHIS based on a certain degree of compulsoriness (the voluntary system is contemplated only on a subordinate basis). Two possible main hurdles to the promulgation of such laws were inferred: the insurance scheme to be adopted and the issue of illegal buildings. Furthermore, the item of natural hazard risk perception was a factor not adequately considered by the bills. Based on the critical scrutiny of the bills and taking advantage of international experiences, the establishment of a voluntary national scheme managed by a public authority with specific competences on NHIS is proposed.
\end{abstract}

Keywords: natural hazard insurance; disaster insurance; built heritage; damage compensation; insurance system; text mining

\section{Introduction}

The rise in number and economic consequences of disasters triggered by natural hazards is feeding the debate about the development of insurance schemes as a risk financing and management instrument.

For many years, the issue of insurance against disasters has been the subject of attention at European level [1]. In 2013, the European Commission dedicated a Green Paper to Insurance against Natural and Anthropogenic Disasters [2]. Moreover, in the important Paris Agreement of COP 21 of December 2015 [3] the explicit reference was included to the need to cooperate, improve understanding, interventions, and support in various fields, such as early warning systems, emergency preparedness, and risk insurance.

In many countries around the world, including Italy, interest in a natural risk insurance system arises from the pursuit to find an efficient way of compensating those who suffer losses, to manage the financial risk of uncertain losses, and to ensure faster rebuilding and building repair times. In Italy, where the occurrence of earthquakes, floods, and landslides is responsible for mean annual losses equal to $0.2 \%$ of the national gross domestic product [4], the problem arises as particularly relevant due to both the low penetration rate of hazard insurance and complex aspects and intrinsic limits of the insurance market [5]. Therefore, the debate about building an NHIS is an old issue. Particularly, the discussion was born and is remains alive on behalf of the question of how to pay for natural disasters' 
economic consequences, whereas the discussion itself concerns fairness, economic efficiency, political feasibility, and public acceptance [6].

With this in mind and considering that the lessons learned could be a prospect of a future reform, the Italian history of attempts (thirty years long!) to pass a law for building a NHIS was analysed.

The article includes six main sections: (a) the theoretical framework for NHISs; (b) the examination of the different national NHISs; (c) an analysis of the Italian bills by both artificial intelligence (AI)-text mining technique and cross-correlated reading; (d) the main results of the analysis; (e) the discussion of the critical issues emergent from the bill analysis; and (f) the conclusions, limitations, and perspectives of the research, in which some insights about possible future implementation of a NHIS in Italy are argued for.

\section{Theoretical Framework}

A NHIS finds its theoretical foundations in the economic literature, which underlines the effectiveness of the insurance contract as a risk-management tool [7]. In its most basic form, insurance is a mechanism where risks are transferred from one party (the insured) to another party (the insurer) in return for a payment (the premium). Moreover, insurance provides incentives to act in a risk-reducing way, triggering adaptation activities and addressing the underlying physical risks that influence the impact of "natural" disasters. This is why the literature on climate change adaptation and disaster risk reduction includes many references to insurance as an instrument for addressing rising risk levels [8].

In order to define an NHIS, the design of its features become relevant to the discussion, given the purpose of having an effective risk-management tool at a national level. How the insurance scheme is designed and implemented depends on a range of factors.

The main features indicated in the literature are the following [9]:

1. insurance can cover different types of natural hazards and exposures and have different coverage designs (including deductibles, exclusions, and conditions);

2. the insured might seek coverage on a voluntary basis or coverage can be compulsory (or semi-compulsory);

3. insurance can be provided by public or private entities.

Particularly, concerning this last point, such a feature is noticeable in the context of different roles and responsibilities of the public and private sector. Policymakers appear to believe that insurance companies may be involved in delivering public policy goals and they advocate their involvement as a solution, especially in times of limited public budgets [10], such as after the COVID-19 pandemic.

In the different models, the role of the state can take different form: (a) the state can act as regulator of insurance systems or can play a more direct role, as primary insurer, guarantor/reinsurer or "residual insurer"; (b) the state can offer post-event financial assistance, through specific funds or ad hoc measures, financed by tax revenues; (c) finally state can coordinate insurance systems, sometimes through an authority.

Taking into account the results of many contributions in the literature, in the natural hazard insurance market some form of state intervention is considered necessary to face the problems on both the demand side and the supply side. Schwarze and Wagner (2007) [11] introduced the idea of "distorted demand and insufficient supply, factors that are fatally interconnected and mutually escalate each other's effects".

This kind of "disaster syndrome" [12] is inherent in the market, but there is also a fundamental policy failure connected with the need of emergency policies. Helping people ex post with public funds, state reconstruction programs, guaranteeing them support by state emergency aid, not only depressed the demand for insurance, but also diminishes the incentive toward preventive behaviour, and the pressure to take public protection measures.

More recently, Paleari (2018) [13] presented a comparative analysis of the insurance system in the EU-28 countries showing that "very high insurance penetration rates are mostly associated with the direct involvement of the Government in the scheme". How- 
ever, the same author underlined that "very high insurance penetration rates are not only and always associated with compulsory insurance and "the way ex post Government compensation is shaped does not seem to be strongly correlated either to insurance penetration rates or to the voluntary/compulsory nature of the scheme" thus concluding that "as the link between insurance schemes and risk reduction is not automatic, it should be strengthened by adequate supporting measures".

In the following section, the experiences of several countries all over the world are analysed.

\section{Different National Experiences}

Several NHISs have been developed internationally with the common objective being the provision of households with financial protection against losses from natural hazards, as described below. However, they are based on different intervention schemes and modalities. In order to identify possible best practices that can be extended in the Italian scenario, the main characteristics of the different national experiences of Turkey, New Zealand, Japan, California, Germany, Spain, Netherlands, and England are analysed.

In Turkey, a compulsory earthquake insurance scheme, called TCIP (Turkish Catastrophe Insurance Pool), was established in 2000. It requires that all households purchase a specific earthquake insurance policy, with government reinsurance as a support for the entire program [14].

Due to the high threat represented by earthquakes, the New Zealand Government established an "Earthquake Authority" (EQC), a state-owned entity that provides capped insurance to residential buildings, land, and personal contents [15]. It is managed by a board of commissioners who offer insurance contracts as an extension of fire policies, even on a voluntary basis. As a result, more than $90 \%$ of residential properties are financially protected.

In a similar manner, the Japanese government established the "Japan Earthquake Reinsurance" (JER), which offers coverage on residential buildings and undertakes the provision of reinsurance for earthquake risk. However, "private insurers must enrol in the JER, which offers optional earthquake insurance as part of a comprehensive insurance policy" [15].

One of the most interesting systems is CEA, the "California Earthquake Authority". It was established after the Northridge earthquake of 1994, when the major insurance companies announced their intention to stop selling such contracts due to the high losses [16]. It is a publicly managed, privately funded organization, constituting an aggregate of insurance private companies. It provides basic residential earthquake insurance coverage throughout the state, purchased in a voluntary market. In particular, CEA sells insurance contracts as a regulated entity in a voluntary market, using its contracted participating insurers as sales agents, policy administrators, and claim adjusters [17]. The relationship between CEA and participating insurers can be summarized: the CEA policy is designed, priced, and backed by the authority, while participating insurance companies, only, service the CEA policy in conjunction with their homeowner's policies [18]. The CEA's latest Strategic Plan recognizes three main goals: educate, mitigate, and insure, with a significant expansion from its earlier plan, which focused on insuring only. One strategy of CEA concerns the educational aspect, which is managed through its website, main media, and thematic conferences [17]. For these purposes, CEA has expended comparatively large sums on marketing and advertising, committed to visible outreach efforts (including loss mitigation programs). CEA also implements incentive actions to mitigate seismic risk by providing, for example, a reduction in the insurance premium of not less than $5 \%$ of the annual premium or also by carrying out lobbying actions with stakeholders for the approval of laws aimed at favouring the mitigation of seismic risk. As regards the policy's adoption, recently higher levels of policy sales have been recorded [17] even though the state-wide adoption rates for residential earthquake policies has never exceeded $16 \%$, probably due to the high premium [19]. 
In order to reach the three main goals, CEA has a user-friendly website, where potential insurance buyers and policyholders can find most of the information he/she needs, such as: (a) earthquake hazard and risk in California, (b) seismic risk mitigation actions, (c) insurance premium by the estimated-premium calculator tool, (d) personal earthquake preparedness.

Looking at the European landscape, Germany has adopted a market-based natural hazard insurance system in which private insurers provide coverage for extreme events as an extension to building or content insurance forms [11]. In this scenario, the federal government has only limited legal competence regarding protection against natural hazards such as flooding and ex-post compensation. In detail, political responsibilities are distributed between the federal government, federal states and local authorities. Therefore, because of the lack of overarching federal legislation, regulations on disasters differ between federal states [20].

In Spain, in 2008, the so-called "Consorcio de Compensacion de Seguros" (CCS) was established. It operates as a private-public partnership, providing state-guaranteed coverage for the extraordinary risk associated with a voluntary insurance scheme for all hazards. In particular, the CCS provides insurance against natural hazards on a subsidiary basis if the coverage is not explicitly assumed by a private company or the company cannot meet its indemnification obligations [21].

The Netherlands has both a governmental compensation scheme, called "Calamities Compensation Act" (CCA), and a voluntary private flood insurance, the "Neerlandse". The CCA operates with specific "water authorities" and is based on a principle of solidarity that can be applicable in cases in which flooding has been formally declared to be a disaster [22] On the other side, the insurance scheme is based on risk differentiation, such that the costs of premiums are directly related to maps of flood risk. In detail, "the value of the insured property is determined by the home contents and rebuilding value indicator of the Neerlandse [private insurance company] or a taxation report, if from a sworn broker or assessor" [23].

Due to the high exposure to flood events, a joint initiative between the English Gov-

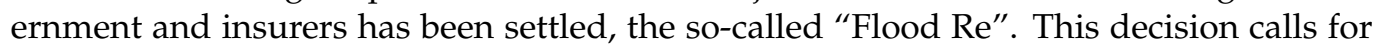
the institution of an insurance pool for properties at high risk of flooding, thanks to an efficient reinsurance scheme. Specifically, it is based on "provision for households under low to normal risk with standard insurance provision, and high-risk properties under the Flood Re pool" [9]. The subsidy for the latter is claimed from a levy taken from all policyholders and imposed on insurers according to their market share. The premiums offered for high-risk households are fixed, dependent on council tax banding, and cover is offered at a set price based on what is felt to be initially affordable" [9]. The aim is to improve the availability and affordability of flood coverage for those people who live in high-risk areas.

In examining each national NHIS supported by national governments, besides the effective political and economic culture spread in any particular country, two of the main reasons for the differences in approach are the levels of exposure and event typology. The link between hazard risk and government-policy scheme is relevant. In other words, for countries with very high levels of risk, they tend to develop programs that focus on that specific risk. In this direction, the cost of these extreme events is to be considered as a key component of the overall NHIS in creating assistance programs and relative projections. In order to effectively reducing the number and the effects of hazards, countries should also tackle all those activities that prefigure disasters. It is for all these reasons that policy makers have to play a primary role in this matter, encouraging and establishing the development of efficient political schemes.

Considering these principles, in the following section the bills for a NHIS proposed in Italy in the last 30 years will be analysed with the intention of outlining a possible future proposal. 


\section{The Long-Lasting Italian Case}

\subsection{Materials and Methods}

The bills aimed in some way at building a NHIS in Italy were identified in specific databases and then analysed. Furthermore, the laws approved by the Italian Parliament aiming to introduce some novelties in the landscape of natural hazard insurance were also selected and considered in our analysis.

The Italian Constitution establishes that its legislative function is exercised collectively by two Chambers, the Chamber of Deputies and the Senate of the Republic. This means that, to become law, a project must be approved in the same text by both the Chambers. The procedure for the formation of the law (the so-called iter) is divided into successive five main phases (Figure 1): (a) the presentation of the bill, (b) the approval of the Chamber to which it was first presented, (c) the transmission of the text to the other Chamber and its approval in the same wording or with modifications (if it is modified, the project passes from one Chamber to another, until it is approved by both in the same wording), (d) the promulgation by the President of the Republic, (e) its publication in the Official Gazette and its entry into force. At the Chamber of Deputies, the bill can be presented by the Government, by each deputy, by at least 50,000 voters as well as from other bodies.

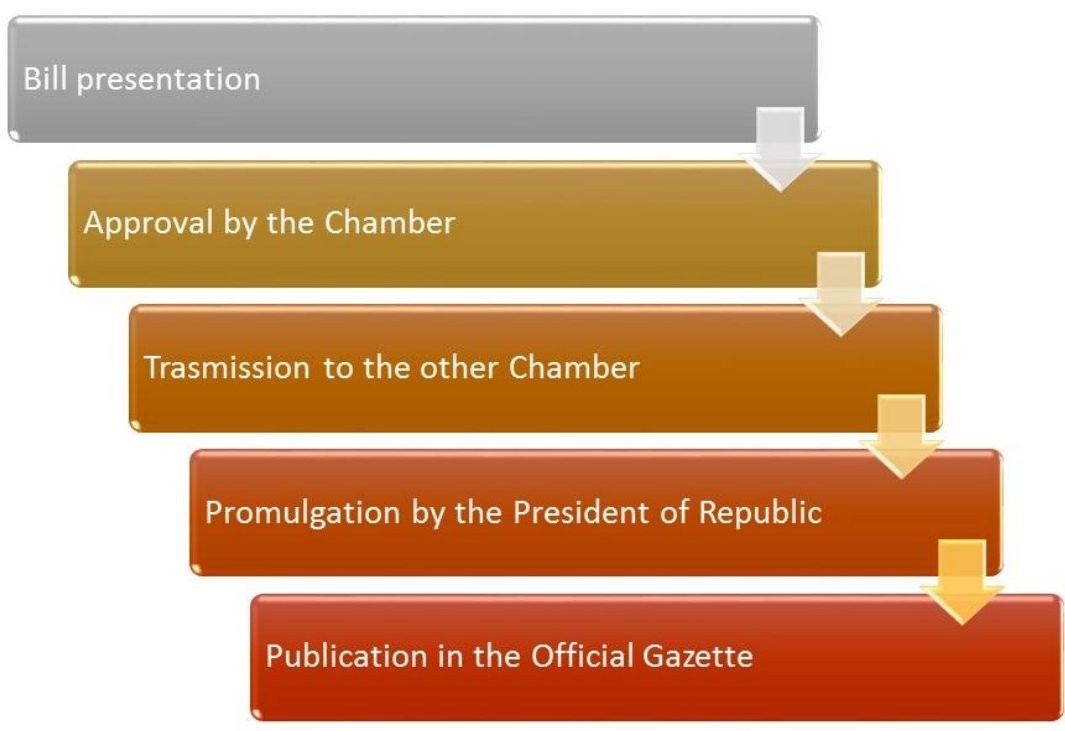

Figure 1. The (simplified) legislative iter in the Italian system.

In order to identify and analyse the bills proposed for the NHIS in Italy eight methodological points illustrated in Figure 2 were followed.

With the aim of searching for bills, the specialized database available on the Senate website (www.senato.it accessed on 4 May 2021) was scrutinized. The search was carried out starting from the VIII legislature, which began on June 20,1979, up to the that still in progress (XVIII). In consideration of the structure of the database, the search was carried out on the complete texts of bills only for the branch of the Senate, while for the search of bills from the Chamber was carried out on summary sheets (cards of treatment).

On the other hand, with regard to the laws approved and in force, the portal of the Italian laws (www.normattiva.it accessed on 8 May 2021) was consulted, which is a textual database with the entire normative corpus of the Italian republic, published since 1946, and with the normative corpus of the Italian monarchy, published from 1861 to 1945. 
- Selection of the databases to be consulted

- Bill extraction by proper search keywords

- English translation of bills

- Overview analysis by Al: data mining approach

- Reading and cross-correlated critical analysis of the bills

- 30 years of bills: the lessons learnt

- International experiences

- Looking at the near future: clues for a national insurance system

Figure 2. Main methodology paths followed to analyse the bills (or laws) on NHIS.

In both official databases, searches were carried out using the keywords calamità naturali (natural calamities), which is the main term used in the Italian legal language to indicate extreme natural events, and assicurazion* (insurance*). Data from both databases were downloaded in May 2021. The results of the searches were then filtered manually, through a detailed examination of their contents with respect to the research objective.

In order to get a general overview of the bills and laws, they were preliminarily investigated by atext-mining approach, using the VOSviewer software (version 1.6.16, Copyright (c) 2009-2020 Nees Jan van Eck and Ludo Waltman, Leiden University, The Netherlands) $[24,25]$. The software builds co-occurrence networks, appropriate for forming a sense of the relationships between words and it is widely used to analyse, from bibliometric perspectives, articles indexed in scientific databases, such as Scopus and/or Web of Science, thereby investigating research trends in different academic fields [26-28]. As far as the authors are aware, this is the first time the software has been used in the scrutiny of legislative documentation.

The software uses a text-mining technique to identify noun phrases. The noun phrases are classified based on a relevance score: a high relevance score is assigned when terms co-occur mainly with a limited set of other noun phrases, so showing a more precise connotation in the field considered. This means that noun phrases with low relevance score are those that tend to be too general and meaningless for the domain of interest: they are omitted from the data processing. The software groups the high-relevance noun phrases (referred to as terms) into clusters to identify possible subfield or research topics. The default option of the software is to select the $60 \%$ most relevant terms among noun phrases that occur at least 10 times. In our analysis, the whole text of the bills or laws were not considered for the extraction of noun phrases, rather, only the sections dealing with the NHIS were analysed. For the purpose of performing the text mining analysis, a preliminary English translation of the considered bills and laws was carried out from Italian. Due to the low numbers of bills and laws, the threshold values of noun phrases were lowered as much as possible, fixing even on single occurrences of a noun phrase. Conversely, the percentage of most relevant terms to be considered was raised to the maximum (100\%). Furthermore, the option to insert a thesaurus text file was considered. This option is helpful in order to merge different spellings of the same term (e.g., "earthquake" and "seismic event") or merging different terms referring to the same concept (e.g., "insurance premium" and "premium"; "private housing" and "private home"). After employing one, the resulting terms were cleaned by deleting irrelevant words (e.g., "Italy", "December", "useful").

The software builds three typologies of maps: network visualizations, overlay visualizations, and density visualizations. The first map shows the items by their label and 
by a circle (or frame). For each term, the size of the term's label and the size of the term's circle (or frame) depends on the weight of the term. Furthermore, the colour of an item indicates the cluster to which it belongs. The overlay visualization is the same as the network visualization except that items are coloured in a different way depending on the user's choice. Lastly, density visualization shows the density of an item at a given point. In our analysis, we comparatively built and analysed network and density visualizations.

\subsection{Results}

4.2.1. Statistics of the Bills and Insight by the Text Mining Approach

Forty-two bills and laws regarding the subject of NHIS were identified. The first act dates back to 1989 and the last to 2019, thus covering a time span of 31 years, with the average of about 1.3 bills or laws per year. The shortest period in which no bills (or laws) were drafted is one year, the longest is three years, the latter traceable at the beginning and at the end of the 31-years period (Figure 3, Table 1).

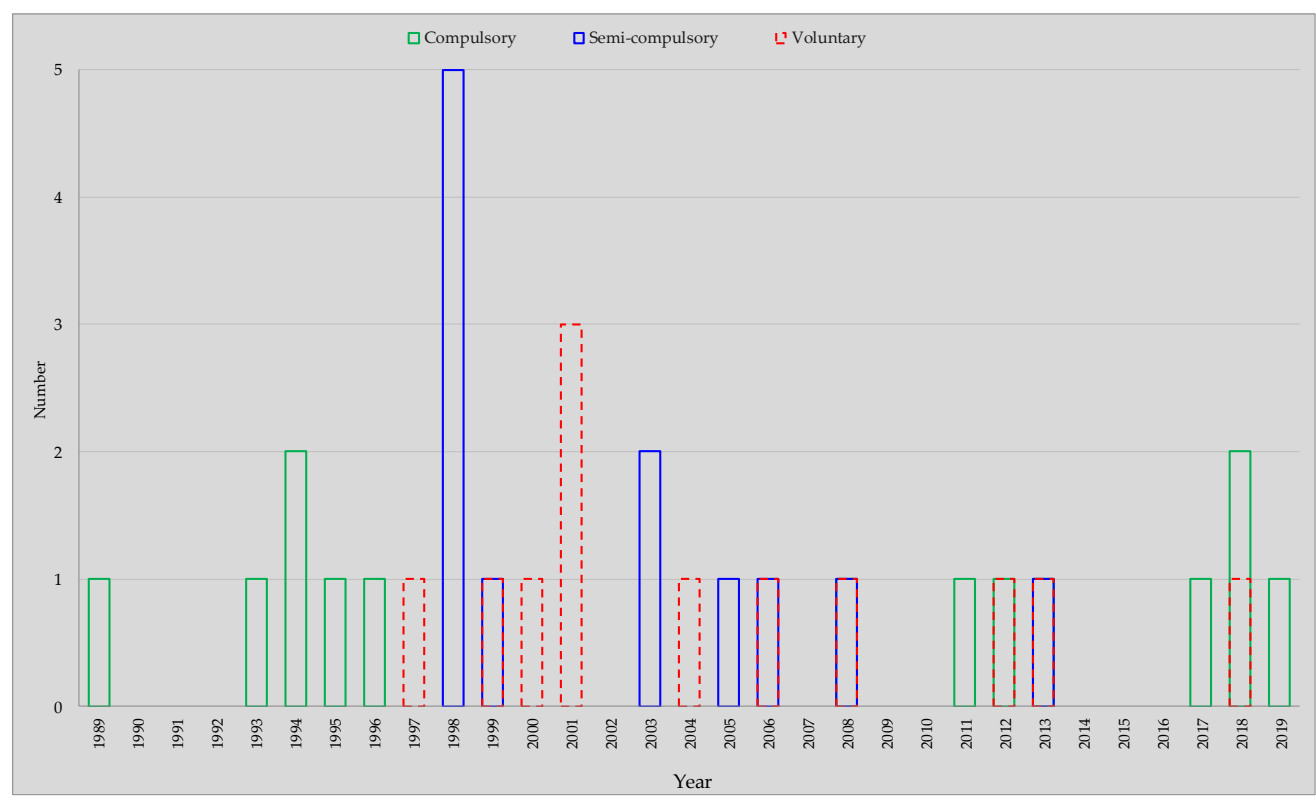

Figure 3. Temporal trend of bills (or laws) dealing with NHIS for Italy. For some years (1999, 2006, 2008, 2012, 2013, and 2018) more than one typology of insurance scheme was proposed.

With regard to the bills proposing an NHIS, it emerged that the prevailing insurance systems proposed, not only for residential assets but also for public buildings, were compulsory in $36.8 \%$ of cases, followed by semi-compulsory (compulsory extension of fire policies coverage undersigned to cover properties) and voluntary ones, each found in $31.6 \%$ of cases. Therefore, bills mainly concerned the proposal of an NHIS based on a certain degree of compulsoriness (seven out of ten proposals); voluntary systems were considered only on a subordinate basis.

The window of thirty-one years can be divided into three main periods: (1) from 1989 to the first half of the nineties of the twentieth century, where the compulsory system clearly prevailed, (2) from the second half of the nineties and up to the first decade of the 2000s, where semi-compulsory or voluntary systems prevailed, (3) in the second decade of the 2000s, in which the compulsory system prevailed again, but was also flanked by the other two schemes, with a relative prevalence of the voluntary one (Figure 3).

The difficulty for Italian politics in tackling the issue is evident from the comparison between the number of bills $(37,88 \%)$ not promulgated and those enacted $(5,12 \%)$. The highest annual number of acts(seven) was recorded in 1998, one year after the earthquake of the Umbria-Marche Apennines of 26 September $1997(\mathrm{Mw}=5.97)$ [29]. 


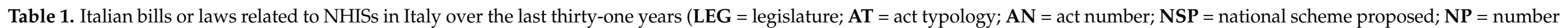
of bill promoters; $\mathbf{B R}=$ branch of the Italian Parliament from which the bills or laws were proposed $(\mathbf{C H}=\mathrm{Chamber}$ of Deputies, $\mathbf{S E}=\mathrm{Senate}$ of the Republic).

\begin{tabular}{|c|c|c|c|c|c|c|c|}
\hline LEG & $\begin{array}{c}\text { Date } \\
(\mathrm{dd} / \mathrm{mm} / \mathrm{yyyy})\end{array}$ & AT & AN & General Aim of the Act & NSP & NP & BR \\
\hline$x$ & 2-Nov-89 & BILL & 4315 & New rules on civil protection & compulsory & 10 & $\mathrm{CH}$ \\
\hline XI & 22-Apr-93 & BILL & 1164 & $\begin{array}{l}\text { Delegation to the Government to issue general provisions on interventions resulting from damage } \\
\text { caused by natural calamities }\end{array}$ & compulsory & 17 & SE \\
\hline XII & 30-June-94 & BILL & 800 & $\begin{array}{l}\text { Delegation to the Government to issue general provisions on interventions resulting from damage } \\
\text { caused by natural calamities }\end{array}$ & compulsory & 1 & $\mathrm{CH}$ \\
\hline XII & 20-July-94 & BILL & 638 & $\begin{array}{l}\text { Delegation to the Government to issue general provisions on interventions resulting from damage } \\
\text { caused by natural calamities }\end{array}$ & compulsory & 7 & SE \\
\hline XII & 4-May-95 & BILL & 2481 & $\begin{array}{l}\text { Delegation to the Government to issue general provisions on interventions resulting from damage } \\
\text { caused by natural calamities }\end{array}$ & compulsory & 1 & $\mathrm{CH}$ \\
\hline XIII & 9-May-96 & BILL & 235 & $\begin{array}{l}\text { Delegation to the Government to issue general provisions on interventions resulting from damage } \\
\text { caused by natural calamities }\end{array}$ & compulsory & 2 & $\mathrm{CH}$ \\
\hline XIII & 19-Dec-96 & $\begin{array}{l}\text { LAW } \\
\text { DECREE }\end{array}$ & 705 & Establishment of capital reserves for the risks of natural calamities & / & - & SE \\
\hline XIII & 9-Dec-97 & BILL & 2926 & $\begin{array}{l}\text { Delegation to the Government for the rationalization of the reimbursement of damages caused by } \\
\text { natural calamities to private property }\end{array}$ & voluntary & 22 & SE \\
\hline XIII & 30-Mar-98 & LAW & 61 & $\begin{array}{l}\text { Conversion into law of the decree-law of } 30 \text { January 1998, n. 6, containing further urgent } \\
\text { interventions in favour of the earthquake-stricken areas of the Marche and Umbria regions and } \\
\text { other areas affected by calamities }\end{array}$ & / & - & - \\
\hline XIII & 14-May-98 & BILL & 3270 & National solidarity fund for the insurance of major environmental risks & / & 1 & SE \\
\hline XIII & 9-June-1998 & BILL & 4966 & $\begin{array}{l}\text { Delegation to the Government for the enactment of rules on the protection of natural calamities. } \\
\text { Provisions concerning the obligation of insurance against risks deriving from natural calamities }\end{array}$ & semi-compulsory & 1 & $\mathrm{CH}$ \\
\hline XIII & 9-June-98 & BILL & 3326 & $\begin{array}{l}\text { Delegation rules for an active defence strategy against natural calamities and insurance against } \\
\text { catastrophe risks }\end{array}$ & semi-compulsory & 34 & SE \\
\hline XIII & 24-June-98 & BILL & 5018 & $\begin{array}{l}\text { Delegation to the Government for the issuing of rules on defence against natural calamities. } \\
\text { Provisions concerning the obligation of insurance against risks deriving from natural calamities }\end{array}$ & semi-compulsory & 10 & $\mathrm{CH}$ \\
\hline XIII & 20-Nov-98 & BILL & 3662 & Public finance measure for stabilization and development & semi-compulsory & 12 & SE \\
\hline XIII & 20-Nov-98 & BILL & 3662-TER & Public finance measures for stabilization and development & semi-compulsory & 12 & SE \\
\hline XIII & 11-Feb-99 & BILL & 3798-I RIST & National Civil Protection Service & voluntary & 21 & SE \\
\hline XIII & 5-May-99 & BILL & 5809-TER & Provisions on insurance and state intervention for natural calamities & semi-compulsory & 4 & $\mathrm{CH}$ \\
\hline XIII & $25-O c t-00$ & BILL & 7385 & Framework law on natural calamities & voluntary & 1 & $\mathrm{CH}$ \\
\hline XIV & 26-Jan-01 & BILL & 533 & $\begin{array}{l}\text { Framework law on interventions for the restoration of damage and the reconstruction following a } \\
\text { calamity or catastrophe }\end{array}$ & voluntary & 7 & SE \\
\hline $\mathrm{XIV}$ & 25-July-01 & BILL & 531 & National Civil Protection Service & voluntary & 14 & SE \\
\hline XIV & 5-Dec-01 & BILL & 930 & Framework law on natural calamities & voluntary & 4 & SE \\
\hline
\end{tabular}


Table 1. Cont

\begin{tabular}{|c|c|c|c|c|c|c|c|}
\hline LEG & $\begin{array}{c}\text { Date } \\
(\mathrm{dd} / \mathrm{mm} / \mathrm{yyyy})\end{array}$ & AT & AN & General Aim of the Act & NSP & NP & BR \\
\hline XIV & 30-Sept-03 & BILL & 2512 & Provisions for the preparation of the annual and multiannual State budget (2004 finance law) & semi-compulsory & 1 & SE \\
\hline XIV & 1-Dec-03 & BILL & 2512-B & Provisions for the preparation of the annual and multiannual State budget (2004 finance law) & semi-compulsory & 1 & SE \\
\hline XIV & 30-Dec-04 & LAW & 311 & Provisions for the preparation of the annual and multiannual State budget (2005 finance law) & voluntary & - & SE \\
\hline XIV & 15-June-05 & BILL & 5921 & $\begin{array}{l}\text { Delegation to the Government for the regulation of insurance to cover risks deriving from natural } \\
\text { calamities }\end{array}$ & semi-compulsory & 3 & $\mathrm{CH}$ \\
\hline $\mathrm{XV}$ & 29-June-06 & BILL & 1238 & $\begin{array}{l}\text { Delegation to the Government for the regulation of insurance to cover risks deriving from natural } \\
\text { calamities }\end{array}$ & semi-compulsory & 1 & $\mathrm{CH}$ \\
\hline $\mathrm{XV}$ & 18-Oct-06 & BILL & 1099 & $\begin{array}{l}\text { Framework law on natural calamities, as well as delegation to the Government for compensation } \\
\text { for damages and for the suspension of terms in civil and tax matters }\end{array}$ & voluntary & 22 & $\mathrm{SE}$ \\
\hline XVI & 29-Apr-08 & BILL & 243 & $\begin{array}{l}\text { Framework law on natural calamities, as well as delegation to the Government for compensation } \\
\text { for damages and for the suspension of terms in civil and tax matters }\end{array}$ & voluntary & 2 & SE \\
\hline XVI & 15-May-08 & BILL & 552 & Safety regulations in schools & compulsory & 1 & SE \\
\hline XVI & 13-Sept-08 & BILL & 1682 & $\begin{array}{l}\text { Delegation to the Government for the regulation of insurance to cover risks deriving from natural } \\
\text { calamities }\end{array}$ & semi-compulsory & 1 & $\mathrm{CH}$ \\
\hline XVI & 27-May-11 & BILL & 2721 & Provisions on urban regeneration to promote housing capacity and the increase of green areas & compulsory & 3 & \\
\hline XVI & 15-May-12 & $\begin{array}{l}\text { LAW } \\
\text { DECREE }\end{array}$ & 59 & Urgent provisions for the reorganization of civil protection & voluntary & - & SE \\
\hline XVI & 19-Dec-12 & BILL & 3631 & $\begin{array}{l}\text { Establishment of compulsory insurance against risks arising from natural calamities, as well as a } \\
\text { Fund for the safety and energy efficiency of buildings }\end{array}$ & compulsory & 29 & SE \\
\hline XVII & 15-Mar-13 & BILL & 124 & Provisions concerning a national plan for the environmental and building heritage requalification & voluntary & 1 & SE \\
\hline XVII & 26-June-13 & BILL & 881 & $\begin{array}{l}\text { Establishment of compulsory insurance against risks arising from natural calamities, as well as a } \\
\text { Fund for the safety and energy efficiency of buildings }\end{array}$ & compulsory & 3 & SE \\
\hline XVII & 19-Sept-17 & BILL & 2904 & $\begin{array}{l}\text { Provisions for the prevention of seismic risk, for post-earthquake reconstruction and the safety of } \\
\text { real estate assets, as well as for the adoption of a national anti-seismic plan }\end{array}$ & compulsory & 5 & SE \\
\hline XVII & 27-Dec-17 & $\begin{array}{l}\text { BUDGET } \\
\text { LAW }\end{array}$ & 205 & Budget law & / & - & SE \\
\hline XVIII & 23-Mar-18 & BILL & 61 & $\begin{array}{l}\text { Provisions for the prevention of seismic risk, for post-earthquake reconstruction and the safety of } \\
\text { real estate assets, as well as for the adoption of a national anti-seismic plan }\end{array}$ & compulsory & 1 & SE \\
\hline XVIII & 23-Mar-18 & BILL & 107 & Safety regulations in schools & compulsory & 2 & SE \\
\hline XVIII & 17-Dec-18 & BILL & 1454 & $\begin{array}{l}\text { Deductibility of expenses incurred for the voluntary insurance of buildings against damage caused } \\
\text { by natural calamities }\end{array}$ & voluntary & 1 & $\mathrm{CH}$ \\
\hline XVIII & 28-June-19 & BILL & 1943 & $\begin{array}{l}\text { Establishment of a national program for the compulsory insurance of private buildings against } \\
\text { damage resulting from natural calamities }\end{array}$ & compulsory & 1 & $\mathrm{CH}$ \\
\hline
\end{tabular}


The bills, when not successful in one legislature, were repeated in one or more subsequent legislatures.

Overall, legislative proposals are mainly made by deputies or senators (mainly in associated form) and subordinately by the Government. The proposals were presented by a single parliamentarian or group thereof belonging to many parties, highlighting the presence of a certain transversal interest of the political class regarding the issue of NHIS.

Bills for an NHIS were usually motivated by the proposer(s) need to guarantee adequate, timely and uniform levels of satisfaction of the repair and reconstruction needs of real estate, as well as to relieve the Italian state of huge economic disbursements after disasters.

The analysis of the bills by the text miming technique shows a map made up of 179 terms divided in two main clusters (Figure 4a): (1) the red, the larger group, which includes 120 terms, (2) the green, made up of 59 items. In the map, the terms related to the same cluster are more interrelated with respect to the terms of the close cluster. In addition, the closer the terms are on the map, the greater their interdependence, i.e. their co-occurrence in the bills (or laws).

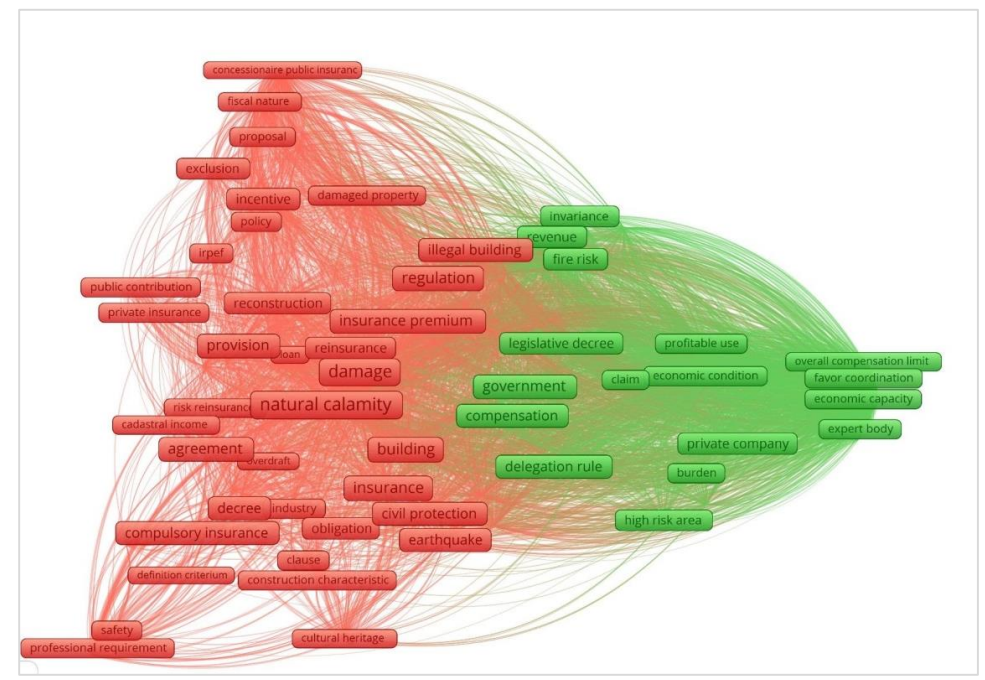

(a)

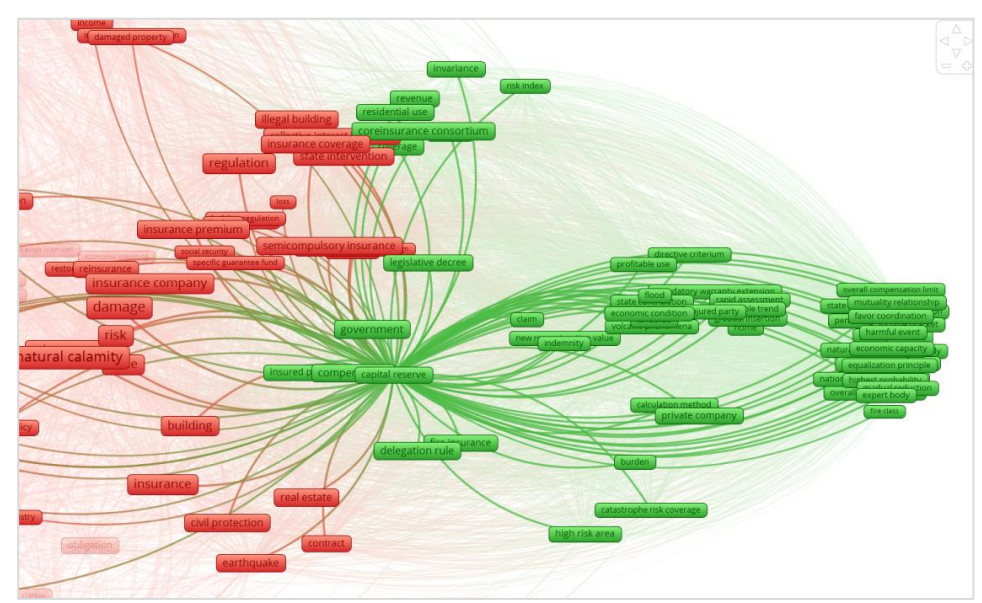

(b)

Figure 4. (a, upper) Co-occurrence term-map related to the bills on natural hazard insurance since 1989; (b, lower) zoom view on the green cluster, with the network links related to the "capital reserve" terms, well representing the main topic of the green cluster (see text). The dimensions of the frames are proportional to the frequency of the terms. 
Thirty are the most frequent words (Table 2). The network is dominated by the "natural calamity" term (40 occurrences) which, as expected, is a central term in the map (Figure 4a) as it is a keyword common to nearly all bills or laws. The other most frequent terms refer mainly to: (a) the assets to be protected (building, private property, real estate), (b) the typology of the NHIS and the contractual aspects of insurance policies (e.g., compulsory, semi-compulsory, voluntary, insurance premium, compensation).

Table 2. Terms of the bills (or laws) on NHIS having higher frequency $(>10)$.

\begin{tabular}{|c|c|c|c|c|}
\hline & TERMS & FREQUENCY & TERMS & FREQUENCY \\
\hline 1. & natural calamity & 40 & 16. delegation rule & 15 \\
\hline 2. & damage & 32 & 17. earthquake & 14 \\
\hline 3. & risk & 30 & 18. illegal building & 14 \\
\hline 4. & insurance company & 24 & $\begin{array}{l}\text { 19. semi-compulsory } \\
\text { insurance }\end{array}$ & 14 \\
\hline 5. & force & 23 & $\begin{array}{l}\text { 20. compulsory } \\
\text { insurance }\end{array}$ & 13 \\
\hline 6. & insurance & 23 & 21. decree & 13 \\
\hline 7. & regulation & 23 & 22. insurance coverage & 13 \\
\hline 8. & building & 22 & 23. real estate & 13 \\
\hline 9. & private property & 21 & $\begin{array}{l}\text { 24. co-reinsurance } \\
\text { consortium }\end{array}$ & 12 \\
\hline 10. & agreement & 20 & 25. state intervention & 12 \\
\hline 11. & government & 17 & 26. voluntary insurance & 12 \\
\hline 12. & insurance premium & 17 & $\begin{array}{l}\text { 27. collective interest } \\
\text { insurance }\end{array}$ & 11 \\
\hline 13. & provision & 17 & 28. contract & 11 \\
\hline 14. & civil protection & 15 & 29. legislative decree & 11 \\
\hline 15. & compensation & 15 & 30. reinsurance & 11 \\
\hline
\end{tabular}

Considering the red cluster (Figure 4a), the terms refer mainly to the insurance schemes to be adopted ("compulsory insurance", "semi compulsory insurance", and "voluntary insurance") with the main general and contractual rules governing them. In the lower portion of the map, the terms such as "hydrogeological instability" and "earthquake" make evident against which natural hazards the "buildings" and "real estate" should be mainly insured. On the other hand, the term "safety" identifies the general framework of the disaster risk reduction policy within which the insurance scheme was often proposed. In the upper part of the red cluster, the terms recall the "policy" of fiscal incentives for insurance coverage (e.g., "deductibility", "incentive", "income", and "irpef", the latter being personal income tax) taking into account the "invariance" principle of "public finance", that is, the granting of incentives without adding to the state budget. 
Considering the green cluster, the terms refer to the damage compensation and the related risk of insurance insolvency to be guaranteed by a "co-reinsurance consortium" and a "capital reserve" by insurers (Figure $4 b$ ).

Taking a closer look at the terms such as their number of connection and degree of link strength, the rules that propose the three insurance schemes seem differ in complexity. In fact, while the obligatory scheme seems to be the least complex, having the lower of both number of connections and link strength (60 terms, total link strength, TLS $=204)$ (Figure 5a), the voluntary one shows an intermediate complexity (92 connections, TLS $=265$ ) (Figure $5 b)$. The greater complexity of the rule seems to belong to the documents that proposed the semi-mandatory regime (141 related terms, TLS $=665$ ) (Figure 5c). Furthermore, analysing the term "semi-compulsory insurance", the highest connection with the green cluster emerges in respect of the other two systems, testifying to the high concern of the promoters of semi-compulsory scheme with respect to the issues of economic sustainability and the potential insolvency of insurance companies (Figure 5c). Moreover, "voluntary insurance" and "semi compulsory" insurance show a greater connection with the upper portion of the red cluster once compared with the "compulsory insurance" term, indicating a higher attention by proponents of non-obligatory insurance systems to facilitate the underwriting of policies by homeowners. In addition, while the two forms of non-compulsory insurance have an interrelation with the theme of "illegal building", the term "compulsory insurance" is not related to it, highlighting a different approach by the proposers to the issue (Figure $5 \mathrm{a}-\mathrm{c}$ ).

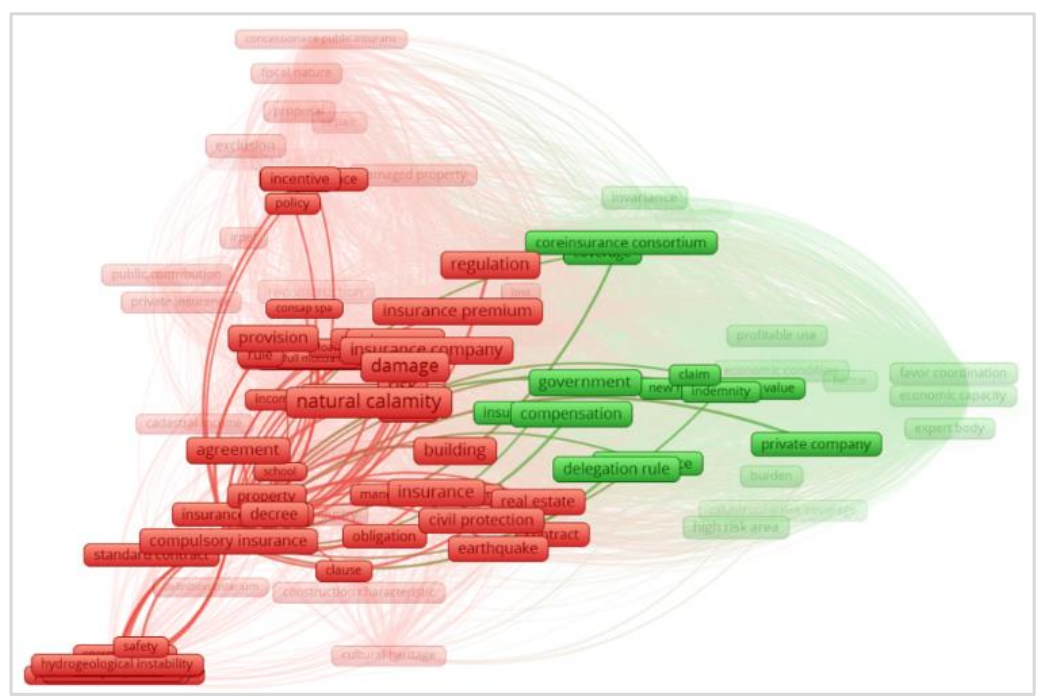

(a)

Figure 5. Cont. 


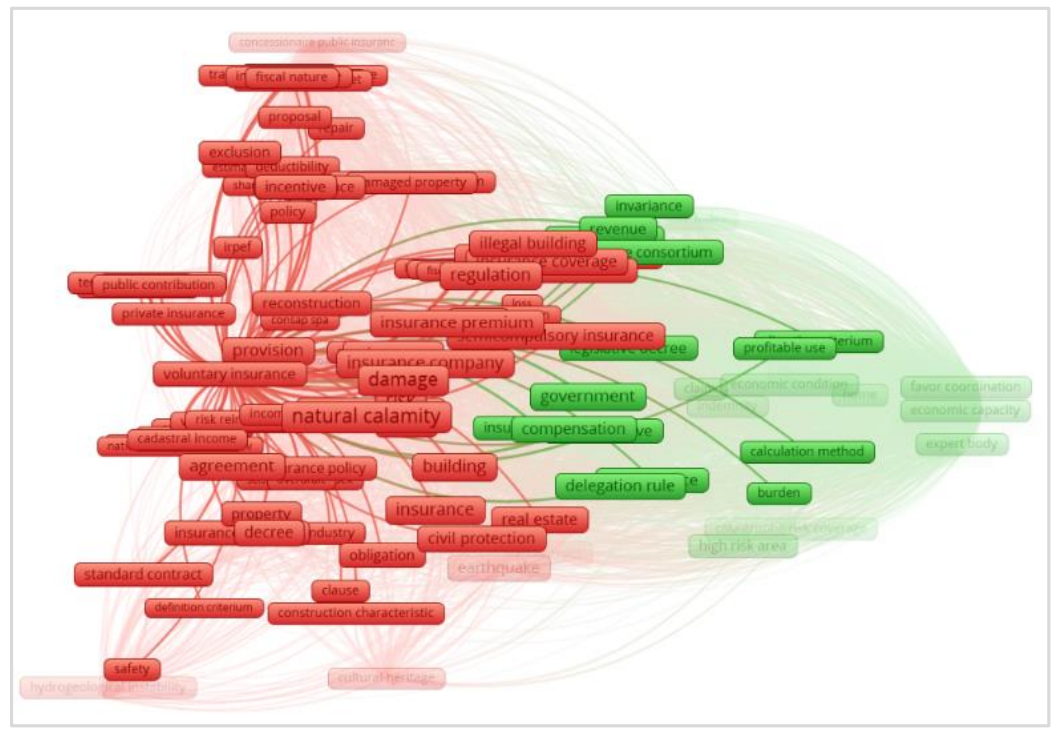

(b)

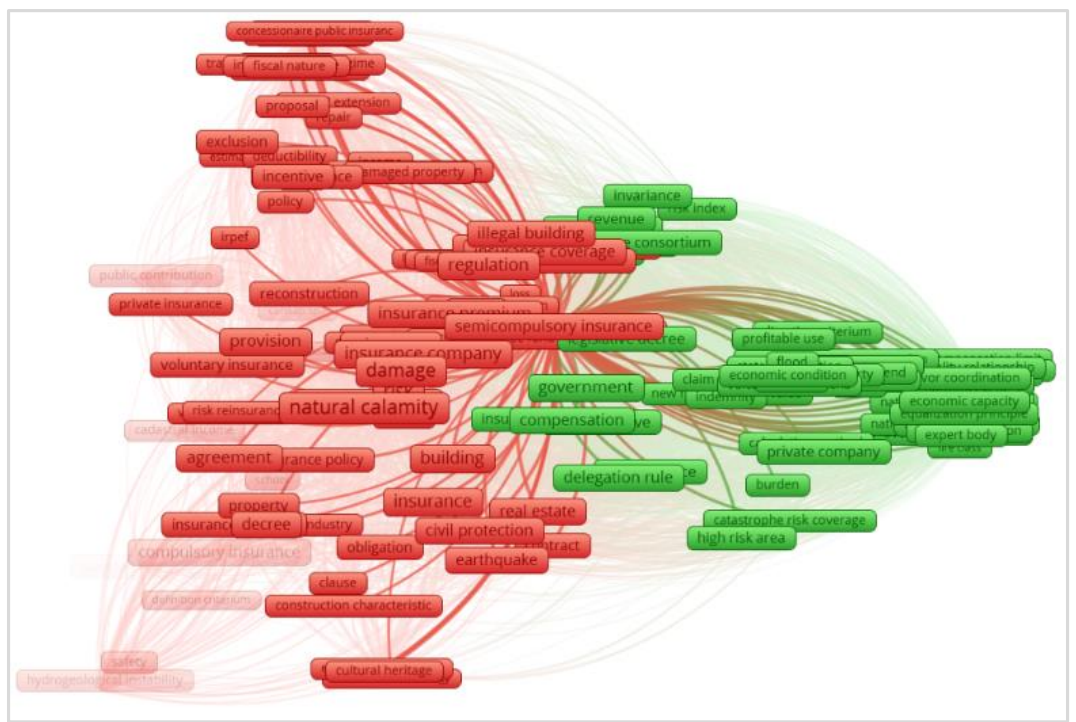

(c)

Figure 5. Map of the co-occurrence terms for Italian bills and laws concerned with an NHI; (aupper) network for "compulsory insurance" term, (b-middle) network for "voluntary insurance" term; (c-lower) network for "semi-compulsory insurance" term. The dimensions of the frames are proportional to the frequency of the terms.

After performing the preliminary analysis by text mining, the main Italian bills were examined in detail by a critical and cross-correlated reading to outline the critical points that might be considered possible obstacles to the building of the NHIS system. The next sections discuss such aspects.

\subsubsection{Analysing Bills' Contents and Main Points}

The first bill (2 November 1989) was proposed about ten years later the 23 November 1980 Irpinia-Basilicata earthquake $(\mathrm{Mw}=6.8)$, one of the strongest earthquakes occurred in Italy since the beginning of the XX century [29-31]. The bill provides for the establishment 
of a National Insurance Fund managed by a specific Service of the National Department of Civil Protection entrusted also for the promotion of insurance coverage. The resources of the Fund consist of the endowment provided for by law and the compulsory insurance premiums paid by citizens, businesses, and local authorities. For the management of the National Insurance Fund, the Minister of Civil Protection can stipulate conventions between consortia of insurance companies.

In 1993, after about four years from the first legislative attempt, a new bill was drafted. The same bill was then to be re-proposed for the next three years. The attempts were provided by the delegation to the government on compensation of damages caused by natural hazards. A compulsory insurance system was proposed for both immovable and movable properties. The insurance scheme was based on three main pillars: (1) a mandatory insurance consortium between the insurance companies, (2) a Fund for the insurance of private assets, wherein insurance premiums can also be brought together, and (3) local bodies, established in each municipality with the task of facilitating the insurance underwriting. The management of the Fund is based on the quite complex concerted actions between ministries and between ministries and a technical committee.

The legislative act of December 1996 does not provide for the establishment of an NHIS, but attempted to establish the conditions for doing so. Indeed, the decreed law established the need for insurance companies dealing with natural hazard coverages to set aside a portion of the premium relating to insurance contracts for the risks of disasters, thus establishing a balance reserve to cover the insolvency risk. The decree, which could be seen as a premise for the development of an economically sustainable NHIS, in some way paved the way for the legislative proposals of the following years.

The next bill that focused attention on the adoption of an NHIS system dates back to December 1997. Taken as a whole, the bill addressed the broader issue of rationalizing the restoration of damage caused by natural hazards to assets owned by individuals. As regards insurance, the bill delegated, to the government, the issuing of specific decrees regulating coverage, proposed on a voluntary basis. In doing so, the bill provides the general guidelines to be followed by the government in enacting these decrees, such as: (1) to limit the state intervention only to cases of disasters declared of national importance by the government, (2) to schedule fiscal insurance incentives but with invariant revenue for the State, (3) to define the maximum limits of insurance reimbursement, (4) to fix the criteria assessing the value of the assets to be insured, (5) to properly integrate the insurance and state compensations, (6) to coordinate insurance companies for catastrophe reinsurance, (7) to list the types of assets, in addition to those built in contrast with environmental, urban planning and building regulations and regulations, for which the intervention of the State for damage compensation must be excluded.

Aside from the less relevant law of March 1998 and the bill of May 1998-which, respectively, addressed the partnership between the public and insurance companies in the compensation of damages and the establishment of a fund for the insurance of major environmental and production risks - the main proposals of 1998 are those presented to the two branches of parliament in June. The three bills are the same and are based on the adoption of a semi-compulsory system. The bills delegate to the government the issuance of general rules of defence against disasters triggered by natural hazards, which, for the first time, were defined for legal purposes. The insurance system is included by the proponents in a broader framework aimed at mitigating risks, through a specific fund, and educating the population to be aware of natural risks; all actions that had not been taken by the state until then, in the opinion of the proposer of the bill(s).

From this last bill, two important points arise: the payment of the premium for the insurance of properties owned by individuals in disadvantaged economic conditions and the coverage of illegal buildings. According to the bills, in the fire insurance contracts relating to real estate owned by private individuals or legal entities, insurance against risks deriving from earthquakes and other natural hazards must be provided by the insurers which cannot refuse to take out the natural hazard coverage. Furthermore, the clause of the 
obligation to extend the coverage was also made compulsory in contracts subsequent to the first renewal. Illegal buildings, as well as cultural heritage and properties in high-hazard areas, are excluded from the obligation to disaster insurance. Furthermore, the bill also provided for tax breaks for both premiums and compensation. The policy and coordination structure was flanked by a national system of assessment and control of the implementation of the provisions of the law, but there is no specific authority with competences on the insurance issue.

The last two bills of November 1998, which still proposed a semi-mandatory scheme, were part of wider legislative interventions aimed at stabilizing public finance and development. The first proposal undertook the issue of the integration between insurance companies and state compensation, postponing the subject to a subsequent regulation by the Ministers. The definition of a specific regulation was also postponed by the second bill of November 1998 so to implement the mandatory extension of fire policies to disasters, partly following the provisions of the December 1997 bill. An aspect that distinguishes this bill (3662-TER, Table 1) from the previous ones, and which will be included in some more recent bills, is its reference to the procedure in the event of absent insurance coverage. Again, also this bill considers the economic conditions of the injured, providing that a share of the damages, between 20 and 50 percent, should be borne by the owner of the damaged property, though, illegal buildings were excluded from any compensation by the State. The bill provided for the regulation of the insurance system, to be defined in agreement between the technically competent ministries.

The draft law of February 1999, which would then been re-proposed in 2001, attempted to introduce an insurance system on a voluntary basis, within the broader legislative perspective, of establishing a national civil protection service. The proposal fixed the percentage of damage potentially remunerable by the state to an amount not exceeding 50 percent, effectively raising the percentage of refundable damage fixed in the 1998 bill.

Three months later (May 1999), the bill addressed one of the critical points outlined above- extending the social and solidarity role of the State to the complete reconstruction of the primary residences of low-income owners. Therefore, the proposal provided for a semi-compulsory insurance, wherein the State safeguards people of low income by ex post aid. The proposal also foresaw the need for a definition (a) of standard contracts, which guarantee an easy settlement of damages and (b) the procedures for risk reinsurance, including by establishing a voluntary consortium between insurance companies.

The bill again delegated to the Government the issue of legislating decrees to regulate the subject of State intervention in the reconstruction of private immovable property destroyed or damaged by natural hazards, including the mandatory extension of fire policies (semi-compulsory insurance) to cover the risk. The proposal undertook and aggregated indications already reported in previous proposals, such as tax incentives for policies, the limitation of state intervention, the assets to be excluded from compensation, the coordination between the companies for catastrophe reinsurance, and the definition of criteria for quick compensation from the companies. The need for a specific information campaign on the subject of insurance was introduced, to be carried out by the Department of Civil Protection.

The bill of October 2000 proposed a voluntary insurance system. The parliamentary act proposed a voluntary insurance system within a framework law on "natural" disasters. The proposal foresaw the government's adoption of legislative decrees on a limited number of aspects, such as the exclusion of any compensation action by both the State and the insurance companies in the case of buildings constructed illegally, the participation in compensation between the State and insurers, and a generic incentive for underwriting policies. The same law was re-proposed just over a year later (December 2001).

The draft of a January 2001 law proposed a voluntary insurance system delegating, to the competent ministries, the burden of establishing: (1) agreements with insurance companies to define standard schemes of contracts with certain indemnity guarantees, (2) a reinsurance system. Probably to facilitate the process of approving the law, the speak- 
ers did not include cases in which the state would not have compensated the owners (illegal buildings). A few months later (July 2001), a new bill based on the direct (fiscal) and indirect incentives (introducing limits on compensation for damages by the State) for voluntary insurance was proposed again. Another attempt to introduce a voluntary system was made in December 2001 and was then re-proposed in 2006 and 2008. The rather general proposal traced the general lines to be detailed through the delegation then conferred with the Government on the subject of compensation for damages.

The bill of September 2003 proposed a semi-mandatory system and a delegation to the Government on the issue of regulating adherence to general principles already included in the previously examined proposals (assets to be excluded, definition of the values of assets for insurance purposes, co-insurance). However, the proposal introduced, for the first time, the need to correlate insurance premiums with territorial risk indices of the different types of natural hazards and provide for deductibles and compensation limits. The proposal also provided for the total exclusion of State intervention for damages suffered from uninsured buildings whose owners' income was above a certain threshold. The bill was proposed again in December of the same year after the approval of the bill in September, with the removal of the paragraph of the bill relating to insurance coverage.

The State finance law for the year 2005 provided for the introduction of a reinsurance company to start a voluntary insurance system. Although the law did not directly address the insurance issue and the methods of implementation of the system, it emphasizes the need to exclude state intervention in covering damage to illegal buildings.

The bill of June 2005, reiterated in other three legislatures (June 2006, September 2008, March 2013), delegated the regulation of insurance to the Government, trying to introduce through by fiscal incentives, again, mandatory extensions against the risks of natural disasters for properties covered by fire insurance policies and the correlating of premiums to risk indexes.

In May 2011, an attempt to introduce limited compulsory insurance was proposed, if only for buildings or structures built within urban regeneration interventions, but the bill was once again not approved. A comparable approach, but based on the encouragement of voluntary insurance, was proposed in 2013 as part of the provisions concerning a national plan for the environmental and building heritage redevelopment, with the aim of determining a significant reduction in cost by the state.

After the 2009 L'Aquila and 2012 Emilia earthquakes, the building of an NHIS system became topical again and another attempt to introduce such a system arrived via the article No. 2: "Coperture assicurative su base volontaria contro i rischi di danni derivanti da calamità naturali" (Voluntary insurance coverage against damage caused by natural disasters) of the executive order No. 59/2012 dealing with "Disposizioni urgenti per il riordino della protezione civile" (Urgent provisions for the rearrangement of the National Civil Protection). The fundamental assumption of the article was to guarantee suitable, timely and uniform reparation and rebuilding actions considering that the State has limited economic resources to cope with the medium-long term consequences caused by natural hazards.

The lack of an agreement between the policymakers in respect of the insurance system to be adopted undermined the efforts [5] and probably stimulated the bill of December 2012, based on the compulsory insurance system. According to the proposal, all public and private properties had to be in possession of insurance against the risks arising from any natural hazard, including seismic events and hydrogeological instability, within a few months of entering into enforced law.

The legislative proposals of the last three years were mainly based on a mandatory insurance system, also providing underwriting an insurance contracts as a binding requirement for the validity of the purchase, sale or rental of properties (bill of September 2017). The latest bill, proposed in June 2019, provides for a very complex mandatory system with "the establishment of a national program for the compulsory insurance of private buildings 
against damage resulting from natural disasters", wherein the State is called upon to play the role of insurer of last resort.

\section{Discussion}

The analysis of the (never promulgated) bills reveals possible reasons for and obstacles to the failure to introduce am NHIS in Italy. The identification of such aspects can be a useful starting point for possible future proposal.

The critical points of discussion are essentially the choice between a (semi-)compulsory versus a voluntary scheme and the coverage of illegal buildings.

\subsection{Compulsory Versus Voluntary NHIS}

From the analysis of legislative attempts made in the last 30 years or so, a gradual approach to the introduction of insurance schemes seems to emerge. After the first bills, themselves based on a compulsory scheme, the next would look at voluntary or semicompulsory systems. However, after the earthquakes of 2009, in L'Aquila, 2012, in Emilia, and 2016, in Central Italy, the enormous damages and the economic burden on state finances pushed the speakers to propose laws based mainly on a mandatory scheme. In this way, the total number of bills proposing an NHIS based on a certain degree of compulsoriness was clearly predominant $(\approx 70 \%)$ respect to the voluntary system.

To introduce a semi-compulsory scheme, some bills obligate companies to sell coverage against natural hazard damages. This rule can discourage insurance companies, who may also fear the risk of insolvency, as bills usually do not refer to the Italian State as the insurer of last resort. Indeed, usually the bills provide for overcoming insolvency through risk reinsurance or the establishment of a voluntary consortium within the insurance companies and the provision of reserve capital.

However, the bills scheduling the State as insurer of last resort may have encountered obstacles to their approval, as they did in other countries, such as Germany [11]. Moreover, the same semi-mandatory schemes that provided for the mandatory extension of the fire policy to the risk of "natural" disasters were also provided for existing contracts. This rule may have discouraged insurers, fearing the risk of clients' withdrawal from basic (fire) property coverage.

The Italian bills proposals were in line with other countries' experiences. In fact, an analysis of the NHISs adopted in different countries shows that the compulsory scheme usually corresponds with a relevant role of the state, even if semi-compulsory or voluntary scheme are more common. In these last cases, very often the purchase of natural hazard insurance coverage is linked with other coverage related to buildings (like the fire insurance contracts). The decision to introduce a compulsory NHIS does not necessarily correspond to a reduction in the insurance market's competitiveness [32], but, generally, compulsory insurance schemes are hard to implement and have unpredictable impacts [33].

The failure to build an NHIS scheme in Italy could be, in some ways, related to the idea that a compulsory or semi-compulsory insurance may be regarded as a "tax" in the context of already high fiscal pressure. Indeed, Italy is in the first places for fiscal pressure among the EU-27 [34]. Moreover, Italians' perception of tax authorities continue to be substantially negative: one study reported citizens' regard it as unfair $(36.2 \%)$, inefficient $(25.5 \%)$ and expensive $(23.7 \%)$. Only $9.9 \%$ considered it efficient and $4.7 \%$ considered it to have solidarity [35]. Therefore, citizens are very sensitive to taxation. In this sense, the introduction of a compulsory insurance policy would be very unpopular with a negative effect for the political party proposing it.

\subsection{The Issue of Illegal Buildings}

Insurance bills usually address unauthorized buildings; indeed, in applying the rules for both insurance and State damage compensation in the event of a disaster, bills frequently exclude properties built illegally from any compensation. If this is certainly acceptable 
in legal principle, it nonetheless probably collides with the extreme complexity of Italian socio-political issues.

Illegal building is defined as an activity of land transformation and the construction/use of buildings that infringes upon enforced territorial planning rules. The widespread practice of unauthorized building is a generalized matter in all countries. What markedly distinguishes the Italian case from the other countries is the way in which the issue has been dealt with in recent decades. In fact, in the last fifty years there has been a lack of a serious effort in returning to the issue. If we thus consider illegal activity according to the notion of double violation, i.e., as a frequent and at the same time unpunished irregularity, the global examples thereof are essentially found in two context: Italy, and a few big cities in developing countries [36]. In Italy, the phenomenon is mainly due to the transfer of population from the countryside to cities after the end of the Second World War [37].

In compliance with the 2000 BES report (Benessere equo e sostenibile-Fair and Sustainable Wellbeing, https://www.istat.it/it/archivio/254761 accessed on 9 September 2021), the Italian illegal building index, referring to residential constructions, stood at 17.7 illegal per 100 authorized constructions. The rate reached 45.2 illegal buildings per 100 authorized in Southern Italy, but was also of concern in Central Italy, where the value is close to the Italian average. Moreover, the amount of illegal buildings to be demolished by local authorities is so high that some authors [38] have proposed a computer-based approach to define pulling down priorities based on prearranged criteria.

The so-called abusivismo edilizio takes on particular importance in Southern Italy where the abusivismo di necessità (necessary for family home) is joined with abusivismo di speculazione (aimed at speculation) [39].

Over the years, the Italian Parliament approved three building amnesties (the so-called condono edilizio) in 1985, 1994, and 2003 which did not solve the problem instilling further waves of spontaneous building, encouraging the belief that further amnesties would follow to allow illegal situations to be remedied by law [39]. Moreover, the same approvals by the Italian Parliament of the building amnesties could be interpreted as an attempt by the institutions to pursue widespread illegality that, in this way, is officially accepted [40].

Although there were no further amnesties, from January 2010 to December 2012, at least 17 bills were sponsored that, however, were not enacted [37]. This "legislative turmoil" testifies that politicians "ride" the issue of unauthorized buildings for electoral benefit [39]. Therefore, insurance bills that have included restrictions of benefits for owners of neither legal nor safe buildings could have encountered relevant opposition in the parliament, slowing down or blocking the approval iter.

\section{Conclusions, limitations, and Research Perspectives}

As reported in the Introduction, the debate, at the European level, has highlighted that insurance can be a useful tool for managing disasters, especially in times of limited public funding. Drawing inspiration mainly from this motivation, our research aim was to provide possible suggestions for the building of an NHIS in Italy, taking advantage of the lessons learned from the past. In order to reach this aim, the identification and analysis of bills, proposed in the Italian Parliament since the late 1980s, were performed. The use of a text-mining technique, followed by a careful reading of the bills, were the two main methodological steps considered for such purpose.

The results show that more than forty bills were proposed. The (never promulgated) bills were mainly concerned to propose an NHIS based on a certain degree of compulsoriness, and the issue of illegal buildings was considered relevant in many. In this direction, the solutions of these questions seem to emerge as fundamental insights in establishing an Italian NHIS.

In addition, an aspect that the bills did not adequately address and which should be appropriately considered in an NHIS is the need to increase the natural hazard risk perception among citizens. Risk perception is people's subjective judgment of definite peril and how concerned they are with the effects thereof. It influences people to take proper 
actions when dealing with natural hazards, including their decisions to buy insurance coverage [41,42]. Unfortunately, studies in the Italian context report low risk perception. Marincioni et al. (2012) [43] examined a sample of the population involved in the 2009 L'Aquila earthquake $(\mathrm{Mw}=6.3)$ and concluded that the residents of the town had a low risk perception and no awareness of the structural performance of their own buildings. Crescimbene et al. (2014) [44], by the analysis of online tests, concluded that most Italians who live in areas of high seismic hazard have either a low or incorrect risk perception, thus suggesting the need for new communication strategies. Salvati et al. (2014) [45] highlighted that Italians have a greater perception of technological risks greater than of natural risks and consider earthquakes more dangerous than geo-hydrogeological perils. The authors concluded that more actions are needed to increase the population's knowledge of hydrogeological hazards and associated risks.

As Section 2 has outlined, the penetration of natural hazard insurance depends on the solutions to failures related on both the demand and supply sides of the market. Different countries' experiences (Section 3) correspond to several attempts to overcome market failures, characterized by a particular role played by the state. In this perspective, similarly to the experience of CEA described above (Section 3), a permanent public Authority with specific competences in NHIS could be established in Italy, targeted at both facilitating the resolution of the technical aspects related to the introduction of the insurance system and increasing the penetration of insurance policies. This would help to overcome some critical issues found in the bills regarding the generic attribution of NHIS competencies, usually assigned to the government or in consultation between ministries and other technical bodies.

This Authority could be organized to represent the agencies or stakeholders operating in the market or having competence on disasters, such as: the Italian Civil Protection Department (Dipartimento della Protezione Civile https: / /www.protezionecivile.gov.it/ accessed on 10 September 2021), the Association of the Italian Insurance Companies (ANIA https: / / www.ania.it accessed on 10 September 2021), the Institute for Insurance Supervision (IVASS https: / / www.ivass.it accessed on 10 September 2021), universities, and research centres. The Authority, if representative of all market players, would help to solve the issues that, in the past, have effectively blocked establishing an NHIS.

Such Authority could address her activities to solving the issues outlined both on the demand and on the supply sides of the disaster insurance market.

On the demand side, concerning (low) risk perception among citizens, the Authority could coordinate both the risk-education activities of citizens and the monitoring of the scheme's introduction over time. In addition, fiscal incentives could be introduced to stimulate insurance demand, trying to overcome the problem of the vagueness of some bills that could have made the technical control bodies skeptical of the economic sustainability of the proposal. Indeed, some bills have suggested tax incentives to underwrite natural hazards coverage, assuming no revenue variance for the state, but not supporting claims with economic impact estimates.

On the other side of the market, the supply side, Italian insurance companies do not seem sensitive to increasing the penetration of this kind of insurance in the market, given the problems connected with their potential high financial exposure and the consequent high levels of premiums. As stated in [5]: "the Italian private insurance market has some limits on the supply side, and in fact, the insurability is not guaranteed for all hazards and properties. The premium formation presents some drawbacks, and the compensation for the insured may not be sufficient to achieve the rebuilding/repairing aims". Considering the failure of the bills, the clear majority of which provided for a certain degree of compulsoriness by the owners of the properties, the Authority could act, in Italy, as the CEA does in the USA, being a private-market participant in a voluntary market for residential insurance but within a mandatory offer system. In relation to the abovementioned issue of the choice between a compulsory and a voluntary system (Section 5.1), a public authority, acting as a player in the market, could guarantee the correct use of 
a voluntary scheme. Particularly, a system that guarantees a fair premium (calculated according to actuarial techniques), but also a possible subsidy system that supports people with lower incomes.

The incentive for voluntary insurance underwriting by the Authority should focus on the advantages of an insurance system. One of these could be the possible shorter times required for compensation of damages compared to those guaranteed by the state, especially in conditions of intensified economic crisis and sharp worsening of the state budget due to the COVID-19 pandemic.

Moreover, the introduction of a public Authority in Italy would be done, as usual, in pursuit of the principle of neutrality with respect to political parties [46] and this would help to detect the problem of any unpopularity connected to the introduction of an NHIS system. The public Authority could also directly coordinate: (a) risk-mitigation plans and the relative legislative initiative aimed at supplying fiscal incentives (e.g., Superbonus 110\%, the fiscal incentives for energy saving and seismic vulnerability reduction interventions) linking tax incentives to the stipulation of insurance policies; (b) action plans aimed at rising natural hazard risk awareness through a dedicated web site, meetings and community engagement, also benefitting from big data [47,48].

In addition, the Authority could act as insurer of last resort, providing protection against those risks that the private sector is unable or unwilling to bear. As an example, a coverage cap could be set, beyond which the state intervenes, offering financial resources to those people affected by a disaster. This strategy might guarantee market stability, increasing, therefore, the efficiency and effectiveness in the country's policy process for improving outcomes. However, acting as insurer of last resort could create moral hazards. It is therefore necessary to set up strong incentives for beneficiaries to monitor and reduce their risk, using a bonus-malus system and risk-based premiums. Hence, the Government should aim to support rather than undermine the private sector market, focusing on addressing market failures.

On another perspectives, the Authority could overcome the difficulties related to illegal construction (Section 5.2) by separating the rules of natural hazards insurance from the more general rules, defined in several bills, on the regulation of the state action and intervention in the event of a disaster, thus mitigating possible political conflicts.

For all the reasons analysed above, a public organization that operates with suitable and transparent independence and that is unambiguously directed to operating in the public interest under recognized financial, management, and scientific/engineering principles, could finally guarantee, in Italy's near future, an efficient and affective NHIS scheme, helpful in safeguarding private homes from the consequences of disasters.

Concluding, the results of our research may be useful to policymakers and insurance companies in finding the appropriate political, legislative and technical solutions to overcome the obstacles that seem to have precluded the legislative iter for the establishment of an NHIS in Italy. Furthermore, the methodological approach adopted may be fruitful to the scientific community, as it suggests an original investigation criteria for examining insurance bills (the integrated use of text mining and direct reading). Indeed, the approach can be extended to other national contexts wherein an NHIS has not yet been defined but wherein previous attempts have been made.

However, the work has a main limitation. We analysed official documents (bills or laws) but it did not take into account other contextual aspects in the presentation of bills (e.g., the political agenda and the legislative priorities; the economic and social circumstances; the stability of the political system; the conflict of interests between potential stakeholders in the construction of the insurance system, etc.). These considerations can guide future investigations. Moreover, the specific aspects of the new Authority's activities could be investigated to address future decisions of the Italian Parliament.

Author Contributions: Conceptualization, F.T.G. and D.P.; methodology, F.T.G.; software, F.T.G.; validation, F.T.G. and D.P.; resources, F.T.G.; data curation, F.T.G. and D.P.; writing-original draft preparation, F.T.G., D.P. and F.D.M.; writing—review and editing, F.T.G., D.P. and F.D.M.; visual- 
ization, F.T.G.; supervision, F.T.G. All authors have read and agreed to the published version of the manuscript.

Funding: This research received no external funding.

Institutional Review Board Statement: Not Applicable.

Informed Consent Statement: Not Applicable.

Data Availability Statement: Bills and laws are available at the following web sites: www.senato.it accessed on 4 May 2021; www.normattiva.it accessed on 8 May 2021 (see the main text).

Conflicts of Interest: The authors declare no conflict of interest.

\section{References}

1. Schwarze, R.; Wagner, G.G. Natural Hazards Insurance in Europe? Tailored Responses to Climate Change Needed; Working Papers in Economics and Statistics, No. 2009-06; University of Innsbruck, Department of Public Finance: Innsbruck, Austria, 2009.

2. European Commission. Green Paper on the Insurance of Natural and Man-Made Disasters. 2013. Available online: https: / / eur-lex.europa.eu/legal-content/EN/ALL/?uri=CELEX\%3A52013DC0213 (accessed on 27 September 2021).

3. United Nations. Paris Agreement. 2015. Available online: https://unfccc.int/process-and-meetings/the-paris-agreement/theparis-agreement (accessed on 21 September 2021).

4. Neumayer, E.; Barthel, F. Normalising Economic Loss from Natural Disasters: A Global Analysis. Glob. Environ. Chang. 2011, 21, 13-24. [CrossRef]

5. Gizzi, F.T.; Potenza, M.R.; Zotta, C. The Insurance Market of Natural Hazards for Residential Properties in Italy. Open J. Earthq. Res. 2016, 5, 35-61. [CrossRef]

6. Segal, E.; Negev, M.; Feitelson, E.; Zaychik, D. Devising 'policy packages' for seismic retrofitting of residen-ces. Nat. Hazards 2017, 89, 497-519. [CrossRef]

7. Kunreuther, H. Mitigating disaster losses through insurance. J. Risk Uncertain. 1996, 12, 171-187. [CrossRef]

8. Botzen, W.J.W.; van den Burgh, J.C.J.M.; Bower, A.E.L.M. Climate change and increased risk for the insurance sector: A global perspective and an assessment for the Netherlands. Nat. Hazards 2010, 52, 577-598. [CrossRef]

9. Surminski, S.; Eldridge, J. Flood insurance in England-An assessment of the current and newly proposed insurance scheme in the context of rising flood risk. J. Flood Risk Manag. 2017, 10, 415-435. [CrossRef]

10. Collier, S.J.; Savannah, C. Governing urban resilience: Insurance and the problematization of climate change. Econ. Soc. 2021, 50, 275-296. [CrossRef]

11. Schwarze, R.; Wagner, G.G. The political economy of natural disaster insurance: Lessons from the failure of a proposed compulsory insurance scheme in Germany. Eur. Environ. 2007, 17, 403-415. [CrossRef]

12. Kunreuther, H. Strategies for Dealing with Large-Scale and Environmental Risks. In Frontiers in Environmental Economics; Folmer, H., Gabel, L., Gerking, S., Rose, A., Eds.; Edward Elgar: Cheltenham, UK, 2000; pp. 293-318.

13. Paleari, S. Disaster risk insurance: A comparison of national schemes in the EU-28. Int. J. Disaster Risk Reduct. 2018, 35, 101059. [CrossRef]

14. Freeman, P.K.; Scott, K. Comparative analysis of large-scale catastrophe compensation schemes, Catastrophic Risks and Insurance. Policy Issues Insur. 2005, 8, 187-234.

15. Nguyen, C.; Noy, I. Insuring Earthquakes: How Would the Californian and Japanese Insurance Programs have Fared Down Under (after the 2011 New Zealand Earthquake)? Working Paper Series from Victoria University of Wellington; School of Economics and Finance: New York, NY, USA, 2017; Volume 6416.

16. Jaffee, D.M.; Russell, T. Behavioral models of insurance: The case of the California Earthquake Authority. Univ. Calif. -Berkeley Work. Pap. 2000, 1-43. Available online: http:/ / citeseerx.ist.psu.edu/viewdoc/download?doi=10.1.1.61.4972\&rep=rep1\&type= pdf (accessed on 10 September 2021).

17. Marshall, D. An Overview of the California Earthquake Authority. Risk Manag. Insur. Rev. 2018, 21, 73-116. [CrossRef]

18. Lin, X. Risk awareness and adverse selection in catastrophe insurance: Evidence from California's residential earthquake insurance market. J. Risk Uncertain. 2020, 61, 43-65. [CrossRef]

19. Pothon, A.; Gueguen, P.; Buisine, S.; Bard, P.Y. California earthquake insurance unpopularity: The issue is the price, not the risk perception. Nat. Hazard Earth Syst. 2019, 19, 1909-1924. [CrossRef]

20. Keskitalo, E.C.H.; Vulturius, G.; Scholten, P. Adaptation to climate change in the insurance sector: Examples for the UK, Germany and the Netherlands. Nat. Hazards 2014, 71, 315-334. [CrossRef]

21. Mysiak, J.; Pérez-Blanco, C.D. Partnerships for disaster risk insurance in the EU. Nat. Hazard Earth Syst. Sci. 2016, 16, $2403-2419$. [CrossRef]

22. Hartlief, T. Privaatrecht in nood. In Crises, Rampen en Recht; Muller, E.R., Hartlief, T., Keulen, B.F., Kummeling, H.R.B.M., Eds.; Kluwer: Deventer, The Netherlands, 2014; pp. 65-194.

23. Suykens, C.; Priest, S.J.; van Doorn-Hoekveld, W.J.; Thuillier, T.; van Rijswick, M. Dealing with flood damages: Will prevention, mitigation, and ex post compensation provide for a resilient triangle? Ecol. Soc. 2016, 21. [CrossRef] 
24. Van Eck, N.J.; Waltman, L. Text mining and visualization using VOSviewer. ISSI Newsl. 2011, 7, 50-54.

25. Van Eck, N.J.; Waltman, L. Visualizing bibliometric networks. In Measuring Scholarly Impact: Methods and Practice; Ding, Y., Rousseau, R., Wolfram, D., Eds.; Springer: Berlin/Heidelberg, Germany, 2014; pp. 285-320.

26. Gizzi, F.T.; Leucci, G. Global Research Patterns on Ground Penetrating Radar (GPR). Surv. Geophys. 2018, 39, 1039-1068. [CrossRef]

27. Gizzi, F.T.; Proto, M.; Potenza, M.R. The Basilicata region (Southern Italy): A natural and 'human-built' open-air laboratory for manifold studies. Research trends over the last 24 years (1994-2017). Geomat. Nat. Hazards Risk 2019, 10, 433-464. [CrossRef]

28. Knapczyk, A.; Francik, S.; Pedryc, N.; Hebda, T. Bibliometric analysis of research trends in engineering for rural development. In Proceedings of the 17th International Scientific Conference Engineering for Rural Development, Jelgava, Latvia, 23-25 May 2018; pp. 700-707.

29. Rovida, A.; Locati, M.; Camassi, R.; Lolli, B.; Gasperini, P. The Italian earthquake catalogue CPTI15. Bull. Earthq. Eng. 2020, 18, 2953-2984. [CrossRef]

30. Gizzi, F.T.; Potenza, M.R.; Zotta, C. 23 November 1980 Irpinia-Basilicata Earthquake (Southern Italy): Towards a Full Knowledge of the Seismic Effects. Bull. Earthq. Eng. 2012, 10, 1109-1131. [CrossRef]

31. Gizzi, F.T.; Potenza, M.R. The Scientific Landscape of November 23rd, 1980 Irpinia-Basilicata Earthquake: Taking Stock of (Almost) 40 Years of Studies. Geosciences 2020, 10, 482. [CrossRef]

32. Porrini, D.; Schwarze, R. Insurance models and European climate change policies: An assessment. Eur. J. Law Econ. 2014, 38, 7-28. [CrossRef]

33. Chen, Y.; Chen, D. The review and analysis of compulsory insurance. Insur. Mark. Co. Anal. Actuar. Comput. 2013, 4, 6-17.

34. Directorate-General for Taxation and Customs Union, Taxation Trends in the European Union: Data for the EU Member States, Iceland, Norway and United Kingdom: 2021 Edition (LU: Publications Office of the European Union, 2021). Available online: https:/ / data.europa.eu/doi/10.2778/732541 (accessed on 10 September 2021).

35. CENSIS. Il Rapporto tra gli Italiani ed il Fisco. Sintesi Della Ricerca Realizzata per il CNDCEC. 2011. Available online: https:/ / oldsite.commercialisti.it/MediaContentResource.ashx? / PortalResources/News/Attachment/b9a3f1bb-cc88-487d-b5 1d-093617c6259b/Gli\%20italiani\%20e\%20il\%20fisco\%20-\%2020gennaio2010.pdf (accessed on 29 September 2021). (In Italian).

36. Predieri, A. Abusivismo Edilizio e Nuove Sanzioni; Nuova Italia Scientifica: Roma, Italy, 1985.

37. Romano, B.; Zullo, F.; Fiorini, L.; Marucci, A. Illegal building in Italy: Too complex a problem for national land policy? Cities 2021, 112, 103159. [CrossRef]

38. Forte, F.; Granata, M.F.; Nesticò, A. A Prioritisation Model Aiding for the Solution of Illegal Buildings Problem. In Computational Science and Its Applications; Springer: Cham, Switzerland, 2016; Volume 9786. [CrossRef]

39. Zanfi, F. The città abusiva in contemporary southern Italy: Illegal building and prospects for change. Urban Stud. 2013, 50, 3428-3445. [CrossRef]

40. Destro, N. Geografia Delle Case Deboli. Oltre L'abusivismo Edilizio. Ph.D. Thesis, Università degli Studi di Padova, Dipartimento delle Scienze Storiche, Geografiche e dell'Antichità, Padua, Italy, 2013.

41. Armaş, I. Earthquake Risk Perception in Bucharest, Romania. Risk Anal. 2006, 26, 1223-1234. [CrossRef]

42. Plapp, T.; Werner, U. Understanding Risk Perception from Natural Hazards: Examples from Germany. In Risk 21—Coping with Risks due to Natural Hazards in the 21st Century; Vullet, A.D., Ed.; Taylor and Francis Group: London, UK, 2006; pp. 101-107.

43. Marincioni, F.; Appiotti, F.; Ferretti, M.; Antinori, C.; Melonaro, P.; Pusceddu, A.; Oreficini-Rosi, R. Perception and Communication of Seismic Risk: The 6 April 2009 L'Aquila Earthquake Case Study. Earthq. Spectra 2012, 28, 159-183. [CrossRef]

44. Crescimbene, M.; La Longa, F.; Camassi, R. What's the Seismic Risk Perception in Italy? In Engineering Geology for Society and Territory; Lollino, G., Arattano, M., Giardino, M., Oliveira, R., Peppeloni, S., Eds.; Springer International Publishing: Cham, Switzerland, 2014; Volume 7, pp. 69-75. [CrossRef]

45. Salvati, P.; Bianchi, C.; Fiorucci, F.; Giostrella, P.; Marchesini, I.; Guzzetti, F. Perception of Flood and Landslide Risk in Italy: A Preliminary Analysis. Nat. Hazards Earth Syst. Sci. Discuss. 2014, 2, 3465-3497. [CrossRef]

46. Martucci, F. The Independence of Regulatory Authorities in Italy. Rev. Française D'administration Publique 2012, 143, 723-734. [CrossRef]

47. Gizzi, F.T.; Kam, J.; Porrini, D. Time windows of opportunities to fight earthquake under-insurance: Evidence from Google Trends. Hum. Soc. Sci. Commun. 2020, 7, 61. [CrossRef]

48. Tan, Y.J.; Maharjan, R. What googling trends tell us about public interest in earthquakes. Seism. Res. Lett. 2018, 89, 653-657. [CrossRef] 